\title{
Microstructure and Charpy Impact Toughness of a 2.25Cr-1Mo-0.25V Steel Weld Metal
}

\author{
Kefan $\mathrm{Wu}^{1,2}$, Yingjie Yan ${ }^{1,2}$, Rui Cao ${ }^{1,2, *} \mathbb{C}$, Xinyu $\mathrm{Li}^{3}$, Yong Jiang ${ }^{3}$, Fei Yang ${ }^{3}$, Xingwang Jia ${ }^{3}$ \\ and Jianhong Chen ${ }^{1,2}$ \\ 1 State Key Laboratory of Advanced Processing and Recycling of Nonferrous Metals, Lanzhou University of \\ Technology, Lanzhou 730050, China; wukefan1030@163.com (K.W.); yjyan@lut.edu.cn (Y.Y.); \\ zchen@lut.edu.cn (J.C.) \\ 2 School of Materials Science and Engineering, Lanzhou University of Technology, Lanzhou 730050, China \\ 3 Atlantic China Welding Consumables, Inc., Zigong 643000, China; lixy5011@126.com (X.L.); \\ jy70c6@yeah.net (Y.J.); feifeimy1977@163.com (F.Y.); wangwang0114@126.com (X.J.) \\ * Correspondence: caorui@lut.edu.cn; Tel.: +86-138-9346-8800
}

Received: 7 June 2020; Accepted: 2 July 2020; Published: 6 July 2020

\begin{abstract}
The demand for heat-resistant steel has increased owing to its utility in numerous devices that must withstand high steam pressures and high temperatures, such as turbine rotors and blades in ultra-supercritical power plants. It is inevitable to join heat-resistance steel part by welding method, so it is important to maintain the toughness of the weld metals. In this study, the microstructure, low-temperature impact toughness, and fracture surface of as-welded and post-weld heat treatment (PWHT) of 2.25Cr-1Mo-0.25V weld metal were investigated. The microstructures of the as-welded and PWHT specimens are granular bainite and ferrite, respectively. This work revealed the relationship between effective microstructure nearby crack initiation origin and low temperature impact toughness for both the as-welded and PWHT specimens. The evolution of the microstructure and prior austenite was then investigated using confocal laser scanning microscopy (CLSM) to observe the formation of coarse ferrite grain structures. A suggestion for enhancing the low-temperature toughness was provided based on the effect of adjusting Mn content and forming acicular ferrite.
\end{abstract}

Keywords: $2.25 \mathrm{Cr}-1 \mathrm{Mo}-0.25 \mathrm{~V}$ weld metal; low-temperature impact toughness; coarse ferrite; austenite; fracture

\section{Introduction}

The rapid development of modern, ultra-supercritical power plants has increased the demand for heat resistant steel in numerous devices that operate at high steam pressures and high temperatures such as turbine rotors, blades, and other rotating parts [1]. Heat-resistant steel has a high temperature strength, creep strength, and corrosion resistance. The ferritic heat-resistant $2.25 \mathrm{Cr}-1 \mathrm{Mo}-0.25 \mathrm{~V}$ steel possesses a higher conductivity and a lower coefficient of thermal expansion than that of austenitic heat-resistant steels. Chromium $(\mathrm{Cr})$ predominantly offers oxidation and corrosion resistance to the ferritic heat-resistant $2.25 \mathrm{Cr}-1 \mathrm{Mo}-0.25 \mathrm{~V}$ steel. An increase in the $\mathrm{Cr}$ content can enhance the hardenability of heat resistant steel owing to its solid-solution strengthening effect [2,3]. At the same time, molybdenum (Mo) has long been used for heat resistance in order to enhance the creep strength. The Mo can effectively reduce the bainite transformation temperature and delay the grain boundary ferrite transformation, thereby promoting the formation of the bainite microstructure at a wide range of cooling rates [4]. The increase in Mo could stabilize the carbide and further contribute to the high-temperature strength of heat-resistant steel. Vanadium (V) has a strong affinity for other elements such as carbon and nitrogen and is, thus, present in the form of Vanadium Carbide (VC) or Vanadium Nitride (VN) precipitates [5]. VN can 
inhibit the growth of austenite grain, while the vanadium can increase the strength by precipitation hardening [6]. The ultimate tensile strength of the $2.25 \mathrm{Cr}-1 \mathrm{Mo}-0.25 \mathrm{~V}$ steel at room temperature is higher $70 \mathrm{MPa}$ than that of 2.25Cr-1Mo steel [7-9]. Meanwhile, due to the weight reduction and energy conservation of the $2.25 \mathrm{Cr}-1 \mathrm{Mo}-0.25 \mathrm{~V}$ steel, it was quickly brought up to the material standards of ASME (USA), ASTM (USA), and JIS (JPN). Jiang et al. [10-12] have investigated the effect of different heat treatments on the microstructure and mechanical properties of $2.25 \mathrm{Cr}-1 \mathrm{Mo}-0.25 \mathrm{~V}$ steels; the results show that appropriate pre-tempering treatment, tempering temperature, and time can enhance the strength and toughness of the steel. Ohtani et al. [13] have investigated the evolution of the microstructure during the creep process. The increase in creep time promotes an increase in the size of the ferrite and the precipitates, thereby resulting in a decrease in the hardness. As $\mathrm{V}$ mainly forms complex precipitates with various elements, numerous pieces of research $[12,14,15]$ have focused on investigating the precipitates in the $2.25 \mathrm{Cr}-1 \mathrm{Mo}-0.25 \mathrm{~V}$ steel. After tempering, the majority of precipitates exist in the form of $\mathrm{M}_{23} \mathrm{C}_{6}$ and $\mathrm{M}_{7} \mathrm{C}_{3}$ as tempering decomposes the $\mathrm{MC}$ precipitates. Moreover, multiple reports have proposed the addition of various alloys/elements to Cr-Mo-V steel, such as $\mathrm{Ti}[16,17], \mathrm{B}[18]$, and $\operatorname{Re}[19,20]$. These elements can improve the strength and toughness by refining the grains and forming microstructure, such as acicular ferrite. However, $2.25 \mathrm{Cr}-1 \mathrm{Mo}-0.25 \mathrm{~V}$ steels frequently fail after long-term service [21,22].

Generally, welded joints have three parts including weld zone, heat affected zone (HAZ) and base metal. This study focuses on weld zone of $2.25 \mathrm{Cr}-1 \mathrm{Mo}-0.25 \mathrm{~V}$ welded joints and called it a weld metal. Several challenges exist when the 2.25Cr-1Mo-0.25V heat-resistant weld metal is subjected to the submerged arc welding (SAW) process. As one of the most commonly used fusion welding processes in the industry, SAW can produce high-quality weld metals with a high deposition rate. However, improper SAW parameters may result in slag inclusions, crystal cracking, and hydrogen cracking. Therefore, the correct choice of SAW parameters and the appropriate flux chemical composition are essential to obtaining a high-quality weld metal. However, the presence of oxygen in the flux is unavoidable and can lead to the formation of oxide inclusions in the weld metal, which are likely to accelerate crack initiation in the Charpy impact test. Moreover, diversity in the microstructure of the weld metal was inevitable because the proportion and size of the microstructure are easily influenced by welding process parameters and differences in the chemical composition of the filler metal. In the multi-pass weld metal, different heat inputs and cooling rates [23] generally influence the proportions of the columnar grain zone and reheated regions [24] and the characteristics of the transformation products, such as grain size, impurity or precipitate coarsening of alloying elements [25], then further affect the tensile strength and impact toughness. Furthermore, the welding speed, inter-pass temperature, and post-weld heat treatment (PWHT) can affect the properties of weld metals, particularly the impact toughness. Several studies have reported that a lower impact toughness or unstable toughness can be achieved in the multi-pass weld metals [26,27]. Thus, the 2.25Cr-1Mo-0.25V weld metals with improved impact toughness have important engineering significance for the safe and stable operation of related metal-based equipment.

The strength and toughness are a pair of contradictory unity. Improving strength will result in the reduction of toughness. Post-weld heat treatment (PWHT) is an effective measure of strengthening and toughening, it can also improve fatigue resistance, prolong service life and remove residual stress. In fact, the most beneficial effects of PWHT is improvements of metallurgical structure by tempering and removal of aging effects [28]. Adjusting the process of Quenching and Tempering (QT) can make phase transformations, further achieving maximum toughness and ductility at a specified hardness and strength [29]. There are some alternative methods for PWHT in recent years. For example, temper bead welding (TBW) has the similar effect with PWHT, which attempts to control deposition of the weld layers during weld repairs [30]; Post-weld normalizing heat treatment (PWNT) can eliminate the $\delta$-ferrite in the weld zone and refine the grain structure, which divided PWHT into two steps, first normalizing and then tempering [31]. 
In order to further enhance the applicability of the heat-resistant $2.25 \mathrm{Cr}-1 \mathrm{Mo}-0.25 \mathrm{~V}$ weld metal, it is critical to understand the relationship between the impact toughness and microstructure of the weld metal. Therefore, this study systematically investigated the low-temperature impact toughness of the heat-resistant $2.25 \mathrm{Cr}-1 \mathrm{Mo}-0.25 \mathrm{~V}$ weld metal manufactured by submerged arc welding and focused on the preferred microstructure of nearby fracture surfaces. The preferred microstructure is characterized by optical microscopy (OM) and scanning electron microscope (SEM). Meanwhile, the novelty of this study is the evolution of those preferred microstructure, which is characterized by confocal laser scanning microscopy (CLSM). According to the analysis and observation of cleavage fracture surface and microstructure, the relationship between the microstructure and low-temperature impact toughness of the as-welded and post-weld heat treatment (PWHT) specimens can be revealed. Based on this relationship, a method for improving the impact toughness was attempted.

\section{Experimental}

\subsection{Materials and Welding Patameters}

In this study, the $2.25 \mathrm{Cr}-1 \mathrm{Mo}-0.25 \mathrm{~V}$ welded joint was obtained by submerged arc welding with 2 beads and 7 layers and the base metal was $2.25 \mathrm{Cr}-1 \mathrm{Mo}-0.25 \mathrm{~V}$ steel. The welding parameters are in accordance with manufacturer data: a pre-heat temperature of $200-250{ }^{\circ} \mathrm{C}$, a voltage of $30 \mathrm{~V}$, a current of $540-550 \mathrm{~A}$, a welding speed of $45 \mathrm{~cm} / \mathrm{min}$, a heat input of $301.7 \mathrm{~kJ} / \mathrm{mm}$, and an inter-pass temperature of $250{ }^{\circ} \mathrm{C}$. The schematic diagram of multi-layer multi-pass weld is shown in Figure 1a and schematic of welded joint is shown in Figure 1b. Due to the characteristics of multi-layer multi-pass welding, columnar grain zone and reheated zone existed in weld zone. All the experimental materials in this study are taken from weld zone in the joint, not involving heat-affected zones and base materials. The chemical composition of the weld zone is displayed in Table 1 measured by Optical Emission Spectrometer (Spectro lab M9, SPECTRO, Kleve, Germany) after welding.
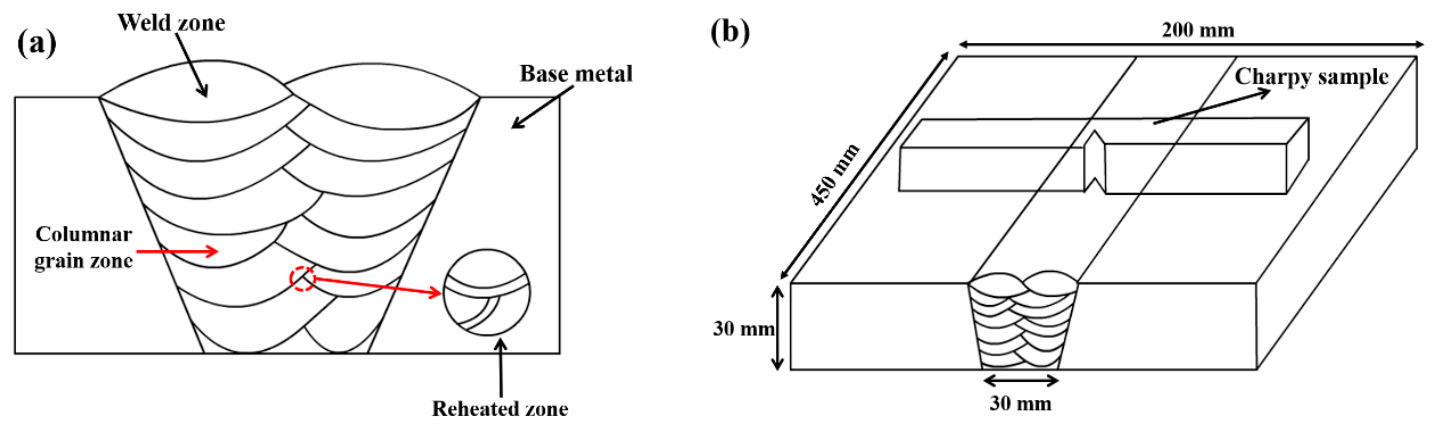

Figure 1. Schematic diagrams of (a) multi-layer multi-pass welding welded joint and (b) welded joint sampling impact specimen.

Table 1. Chemical compositions of the weld zone (wt \%).

\begin{tabular}{cccc}
\hline $\mathbf{C}$ & $\mathbf{M n}$ & $\mathrm{Si}+\mathbf{C r}+\mathbf{M o}+\mathbf{N i}+\mathbf{V}$ & $\mathbf{S}+\mathbf{P}$ \\
\hline 0.094 & 1.04 & 3.9 & 0.0101 \\
\hline
\end{tabular}

\subsection{Thermal Expansion Experiment}

To ensure favorable mechanical properties of the $2.25 \mathrm{Cr}-1 \mathrm{Mo}-0.25 \mathrm{~V}$ weld metal at high temperature, post weld heat treatment (PWHT) must be carried out, and a tempering heat treatment temperature lower than the austenite transformation start temperature $\left(\mathrm{Ac}_{1}\right)$ are required. Thus, it is necessary to measure the austenite transformation start temperature $\left(\mathrm{Ac}_{1}\right)$ and the austenite transformation end temperature $\left(\mathrm{Ac}_{3}\right)$ by a thermal expansion experiment before the PWHT. The specimen heated up to $1100{ }^{\circ} \mathrm{C}$ with a rate of $0.05^{\circ} \mathrm{C} / \mathrm{s}$ in the thermal expansion experiment. The result of $\mathrm{Ac}_{1}$ and $\mathrm{Ac}_{3}$ were $791{ }^{\circ} \mathrm{C}$ and $871^{\circ} \mathrm{C}$, respectively, as shown in Figure 2. 


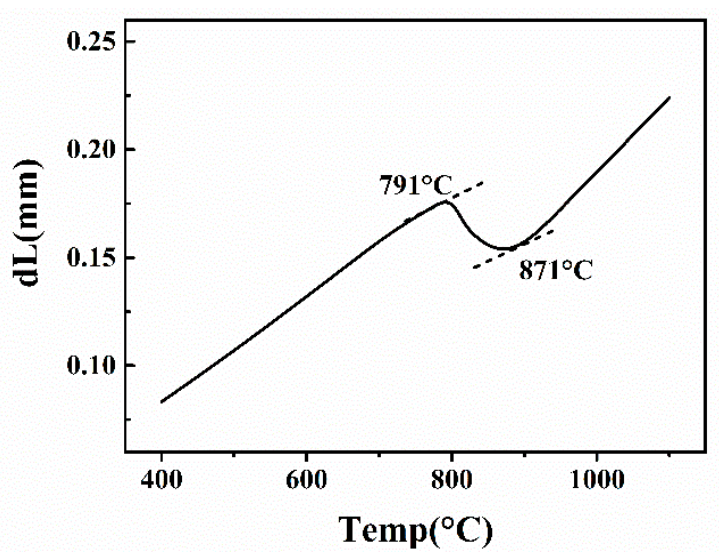

Figure 2. Thermal expansion curve of as-welded specimen.

\subsection{Procedure for Post-Weld Heat Treatment (PWHT)}

Based on the experimental results of the thermal expansion, PWHT was performed in two stages. First, the post heating treatment was performed; after welding, the plate was immediately heated to $350{ }^{\circ} \mathrm{C}$ and maintained for $2 \mathrm{~h}$, then furnace cooled. Second, the principal tempering was performed; the plate was heated to the peak temperature of $705^{\circ} \mathrm{C}$ and maintained for $8 \mathrm{~h}$. Finally, it was cooled to $300{ }^{\circ} \mathrm{C}$ and then air-cooled to room temperature.

\subsection{Charpy Impact Toughness Experiment}

The Charpy impact specimens with dimensions of $10 \mathrm{~mm} \times 10 \mathrm{~mm} \times 55 \mathrm{~mm}$ (Chinese standard GB/T 229-2007) were machined from the welded joint by an electrical discharge cutting machine (DK7745, HENGTIAN, Jiangsu, China), as shown in Figure 1b. The Charpy V-notch is perpendicular to the welding layer to eliminate the effect of V-notch location (at columnar grain zone or reheated zone). The Charpy impact toughness was measured at $-30^{\circ} \mathrm{C}$. The total absorbed energy was identified as the impact toughness. Then, the fracture surfaces were observed by scanning electron microscopy (SEM) (Quanta FEG 450, FEI, Hillsboro, OR, USA). The crack initiation origin on the fracture surface was identified by tracing back the river pattern strips; the fracture surface observation is explained in Section 3.3.

\subsection{Microstructural Analyses}

The metallographic specimens were sampled from the welded joint and then ground, polished, and etched by a $4 \%$ Nital solution. The microstructure was observed by optical microscopy (OM) and SEM with energy-dispersive X-ray spectroscopy (EDS).

To further reveal the relationship between microstructure and the Charpy impact toughness, the present study focused on the effective microstructure at specific areas, such as near the fracture initiation origin and the fracture surface. An electrical discharge cutting machine was used to obtain the observed metallographic sections from the fractured impact specimens. The cutting methods are depicted in Figure 3. The cross-sectional metallographic cutting from the impact specimens is parallel to the notch in order to observe the microstructure at the fracture initiation location, as shown in Figure 3a. The vertical metallographic cutting from the impact specimens is perpendicular to the notch in order to observe the microstructure and retained cracks and to confirm the critical event of crack formation, as shown in Figure 3b. The relationship between microstructure and impact toughness can be explained further by combining two types of metallographic results. 
(a)

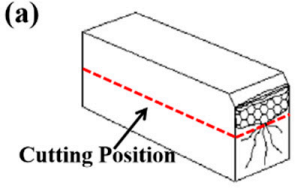

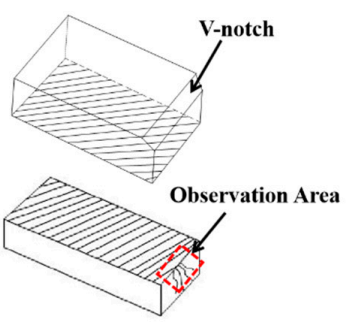

(b)

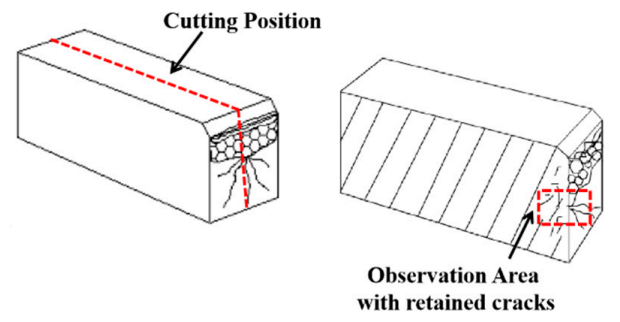

Figure 3. Schematic of metallographic sections from the fractured impact specimens, (a) the cutting cross-section parallel to the notch for observation of microstructure nearby fracture initiation, (b) the cutting vertical-section perpendicular to the notch for the observation of the retained cracks

\subsection{In Situ Observation of Microstructure Evolution}

In order to observe the evolution of the microstructure and prior austenite, confocal laser scanning microscope (CLSM) (VL2000DX-SVF18SP, YONEKURA, Tokyo, Japan) experiments were performed. The specimen with dimensions of $\phi 7.5 \mathrm{~mm} \times 3 \mathrm{~mm}$ was prepared in the as-welded weld zone. It was heated at $1420^{\circ} \mathrm{C}$ with a rate of $10^{\circ} \mathrm{C} / \mathrm{s}$ and held for $240 \mathrm{~s}$ to accelerate the evolution of prior austenite and microstructure, then, the cooling rate of $10^{\circ} \mathrm{C} / \mathrm{s}$ was performed.

\section{Experimental Results}

\subsection{The Microstructure of the Weld Metals}

The microstructure of the as-welded specimen is composed of bainitic ferrite, blocky martensite islands, and retained austenite (M-A constituents) [32], as shown in Figure 4a,c. The slender M-A constituents are distributed in the prior austenite grain boundary, whereas the massive M-A constituents are distributed in the prior austenite grain boundary, respectively. The microstructure of PWHT specimens is shown in Figure $4 \mathrm{~b}$. After tempering at the peak temperature of $705{ }^{\circ} \mathrm{C}$ and holding for $8 \mathrm{~h}$, the microstructure transformed into ferrite and carbide precipitates, which are distributed in the ferrite grain boundaries, as shown in Figure $4 \mathrm{~d}$. The carbide precipitates in the $2.25 \mathrm{Cr}-1 \mathrm{Mo}-0.25 \mathrm{~V}$ weld metal are usually regarded as $M C, M_{7} C_{3}$, and $M_{23} C_{6}$, where the " $M$ " represents metallic elements such as $\mathrm{Cr}, \mathrm{Mo}, \mathrm{V}$, and Fe [11,14].
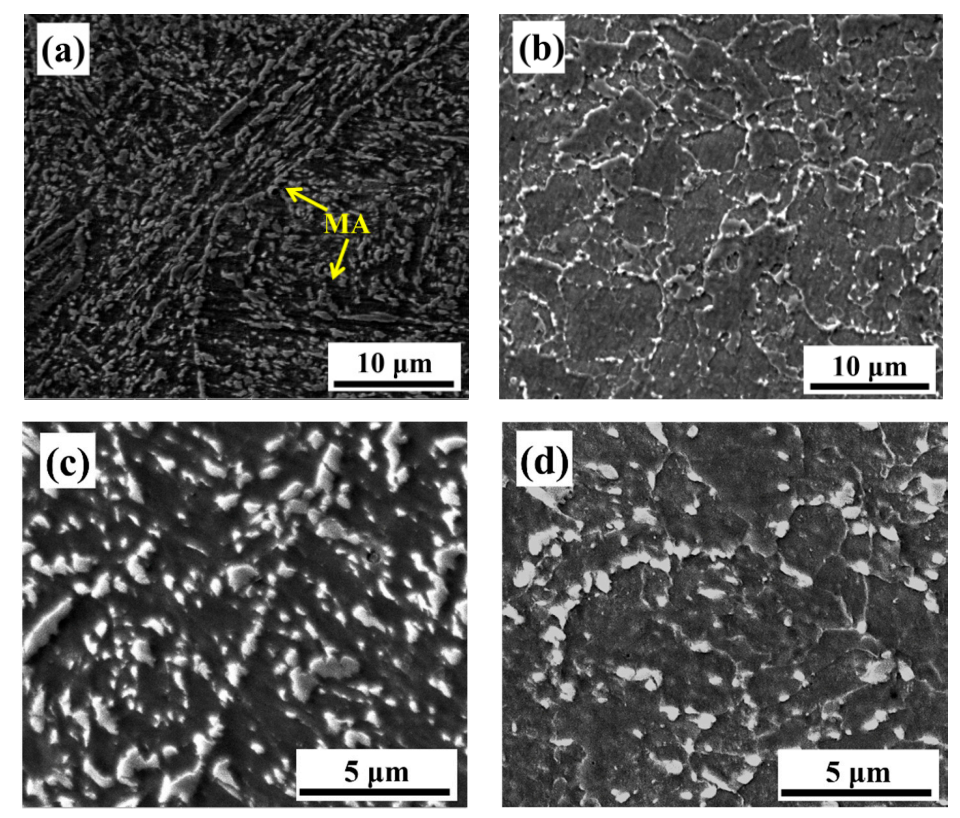

Figure 4. Microstructure of the weld metal for (a) as-welded and (b) post-weld heat treatment (PWHT) specimens; high magnification images of the weld metal for (c) as-welded and (d) PWHT specimens. 


\subsection{Mechanical Properties of the Weld Metals}

The mechanical properties tests were performed for the as-welded and PWHT specimens. The tensile results at $20^{\circ} \mathrm{C}$ are listed in Table 2. Here the mechanical properties standard of $2.25 \mathrm{Cr}-1 \mathrm{Mo}-0.25 \mathrm{~V}$ steel (base metal) is also presented (ASTM A542D C1 4a). The measured yield strength (YS) and ultimate tensile strength (UTS) of the PWHT specimen are $581 \mathrm{MPa}$ and $695 \mathrm{MPa}$, respectively, which are lower than that of the as-welded specimen (709 MPa (YS), $965 \mathrm{MPa}$ (UTS)). Both as-welded and PWHT specimens are meeting the strength standard. The hardness results are presented in Figure 5. The hardness of the as-welded and PWHT specimens are within the ranges of 280-380 HV and 210-260 HV, respectively. The SEM images of the hardness indentation and microstructure corresponding to the hardness value are also shown in Figure 5. Although PWHT decreases the yield strength and ultimate tensile strength, the technique still satisfies the strength requirements of the heat-resistant weld metal at $20{ }^{\circ} \mathrm{C}$.

Table 2. Mechanical properties of the weld zone.

\begin{tabular}{ccccc}
\hline Specimens & YS(MPa) & UTS(MPa) & $\mathbf{\Psi ( \% )}$ & Charpy Impact Energy (J) \\
\hline As-welded & 709 & 965 & $64 \%$ & $6,6,7\left(-30^{\circ} \mathrm{C}\right)$ \\
PWHT & 581 & 695 & $71 \%$ & $24,32,36\left(-30{ }^{\circ} \mathrm{C}\right)$ \\
Standard (BM) & $\geq 415$ & $585-760$ & $\geq 45$ & $\geq 54\left(-18^{\circ} \mathrm{C}\right)$ \\
\hline
\end{tabular}

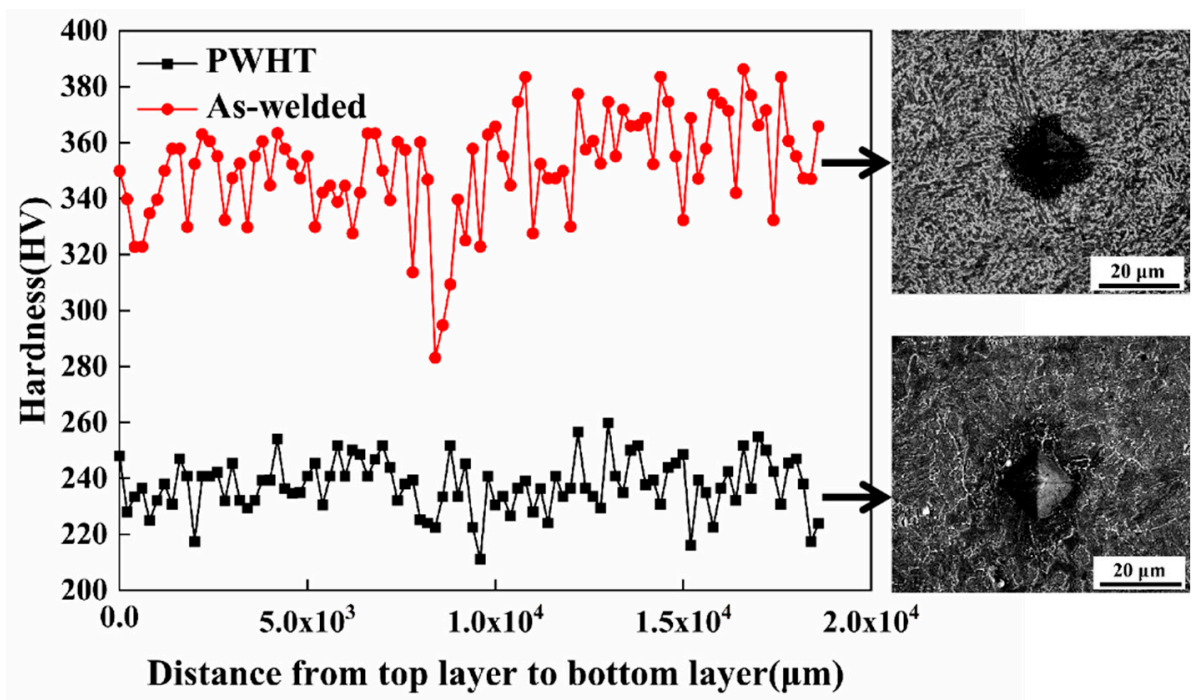

Figure 5. Hardness of the weld metal for as-welded and PWHT specimens.

The reduction of the cross-sectional area $(\Psi)$ and Charpy impact toughness are also presented in Table 2. The PWHT process increases the plasticity and results in improved impact toughness from a range of 6-7 J to that of $30-36 \mathrm{~J}$ at $-30^{\circ} \mathrm{C}$. However, according to the impact energy standard of base metal, the impact toughness of the PWHT specimens is still low and needs to be improved further. The proposed method of improvement in this study is detailed in Section 3.6.

\subsection{Fracture Surface of the Impact Specimens}

The crack initiation origin is identified by tracing back the river pattern strips on the fracture surface. In order to identify the relationship between impact toughness and fracture surface, four parameters of the fracture surface are defined in Refs. [33,34]. These parameters are the stretch zone width (SZW), fibrous crack length (SCL), the distance from the crack initiation site to the fibrous $\operatorname{crack}\left(\mathrm{x}_{\mathrm{f}}\right)$, and the distance from the crack initiation location to the original notch root $\left(\mathrm{X}_{\mathrm{f}}\right)$. The four parameters are related based on the equation $\mathrm{X}_{\mathrm{f}}=\mathrm{SZW}+\mathrm{SCL}+\mathrm{x}_{\mathrm{f}}$, where the sum of SZW and SCL can directly indicate the level of toughness. The corresponding regions are marked in the impact fracture surface of the PWHT specimen with an impact toughness of $32 \mathrm{~J}$, as shown in Figure 6. 


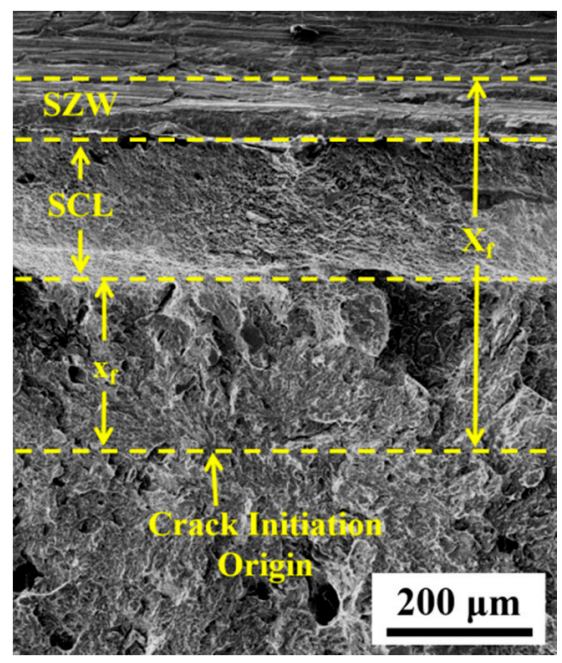

Figure 6. Macro-fracture surface showing the integrating measurements of stretch zone width (SZW), fibrous crack length (SCL), and the $\mathrm{x}_{\mathrm{f}}$ from PWHT specimen.

To further investigate the difference in low-temperature impact toughness between the as-welded and PWHT specimens, the fracture surfaces of the specimens were compared in Figure 7. Figure 7a,b show the fracture surface of the as-welded specimen, while Figure $7 c, d$ show the fracture surface of the PWHT specimen. The fracture surface is composed of the SZW without the typical feature of the nearby V-notch, SCL with dimple feature, and brittle cleavage fracture zone. The fracture initiation origin is tracked by river line features at low magnification, as shown in Figure $7 \mathrm{a}, \mathrm{c}$. Figure $7 \mathrm{~b}, \mathrm{~d}$ illustrate the magnification of the fracture initiation origin of the as-welded and PWHT specimens, respectively. Quasi-cleavage fracture dominates the fracture surface of the as-welded and PWHT specimens, as shown in Figure 7a,c. More tear ridges with dimples exist in the PWHT fracture surface, which is also one of the factors that render the toughness of the PWHT specimen higher than that of the as-welded specimen, as shown in Figure $7 \mathrm{~b}$,d.
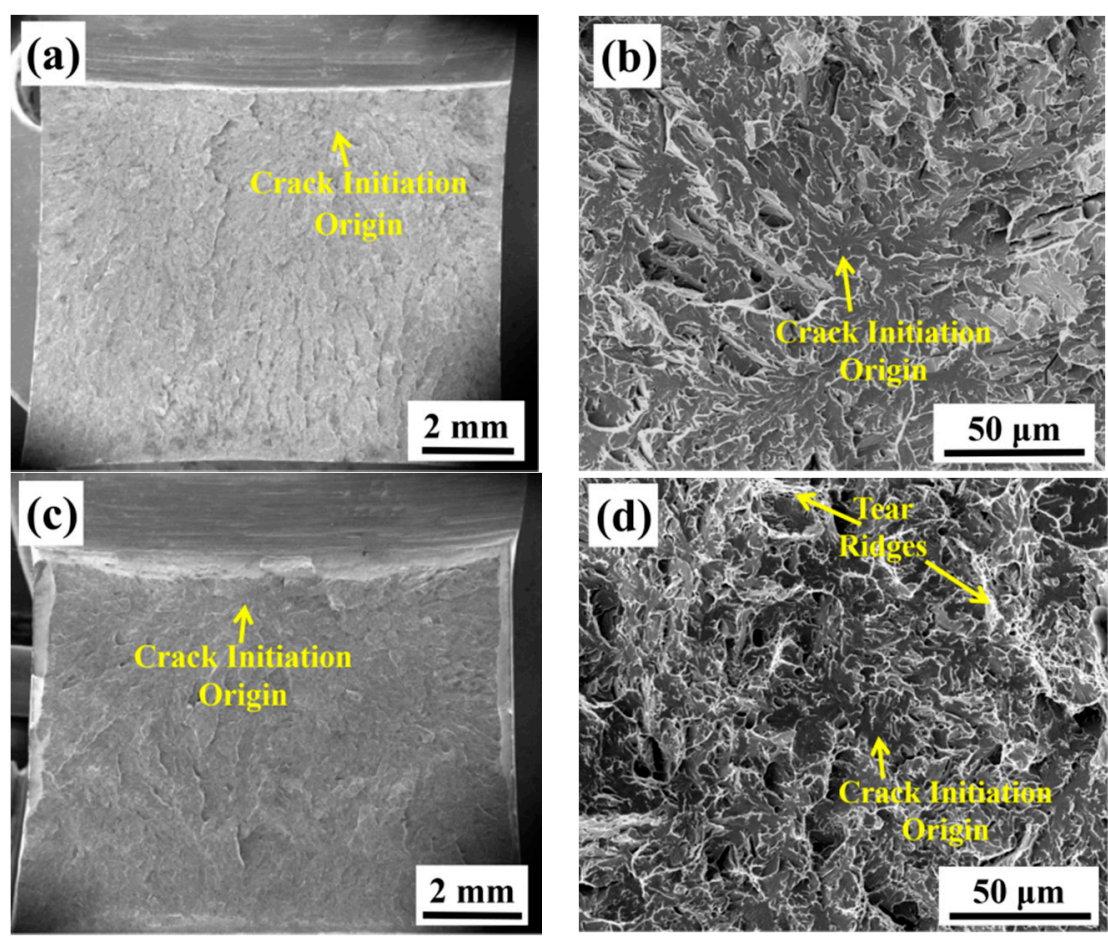

Figure 7. Fracture surface of as-welded specimen $(\mathbf{a}, \mathbf{b})$ and PWHT specimen $(\mathbf{c}, \mathbf{d})$. 
The microscopic parameters of the fracture surface can be measured, as shown in Table 3 . The sum of the SZW and SCL characterizing the level of impact toughness increased significantly after PWHT. However, the relationship between toughness and fracture surface should be compared one-to-one. The parameters of the fracture surface cannot explain the reason for different toughness values. In fact, the variation in the impact toughness is caused by the dissimilarity between granular bainite for the as-welded specimen and ferrite for the PWHT specimen.

Table 3. Impact toughness of the weld metals.

\begin{tabular}{|c|c|c|c|c|c|}
\hline As-Welded & $\begin{array}{l}\text { Impact Toughness } \\
\left(-30^{\circ} \mathrm{C}\right)(\mathrm{J})\end{array}$ & $x_{f}(\mu \mathrm{m})$ & $\operatorname{SCL}(\mu \mathrm{m})$ & $\mathrm{SZW}(\mu \mathrm{m})$ & $X_{f}(\mu \mathrm{m})$ \\
\hline 1 & 6 & 188.6 & 31.1 & 47.7 & 267.4 \\
\hline 2 & 6 & 258 & 29 & 31.1 & 318.1 \\
\hline 3 & 7 & 185.8 & 37.3 & 65.3 & 288.4 \\
\hline PWHT & $\begin{array}{l}\text { Impact toughness } \\
\quad\left(-30^{\circ} \mathrm{C}\right)(\mathrm{J})\end{array}$ & $x_{f}(\mu \mathrm{m})$ & $\operatorname{SCL}(\mu \mathrm{m})$ & $\mathrm{SZW}(\mu \mathrm{m})$ & $X_{f}(\mu \mathrm{m})$ \\
\hline 1 & 30 & 587.7 & 365 & 117.5 & 1070.2 \\
\hline 2 & 32 & 458 & 432 & 267.7 & 1157.7 \\
\hline 3 & 36 & 504.4 & 511 & 286.4 & 1301.8 \\
\hline HM(Mn1.27wt\%) & $\begin{array}{l}\text { Impact toughness } \\
\left(-30^{\circ} \mathrm{C}\right)(\mathrm{J})\end{array}$ & $x_{f}(\mu \mathrm{m})$ & $\operatorname{SCL}(\mu \mathrm{m})$ & $\mathrm{SZW}(\mu \mathrm{m})$ & $X_{f}(\mu \mathrm{m})$ \\
\hline 1 & 95 & 571 & 1119.2 & 340.4 & 2030.6 \\
\hline 2 & 132 & 830 & 2267.3 & 271.2 & 3368.5 \\
\hline 3 & 157 & 629.2 & 3160.9 & 219.5 & 4009.6 \\
\hline
\end{tabular}

\subsection{Effective Microstructure for Determining Impact Toughness}

Various scholars have postulated the relationship between microstructure and toughness. Pickering et al. [35] indicated that the ductile-brittle transition temperature (DBTT) is represented by the following:

$$
\text { DBTT }=\mathrm{f}(\text { composition })+\mathrm{g}(\text { strength })-11.5 \times(\mathrm{d})^{-1 / 2}
$$

Where $\mathrm{f}$ and $\mathrm{g}$ are functions of composition and strength, $\mathrm{d}$ is the effective grain size. A decreased grain size is beneficial for decreasing the DBTT and improving the low-temperature toughness [12]. Figure $4 \mathrm{~b}$ shows the microstructure of the $2.25 \mathrm{Cr}-1 \mathrm{Mo}-0.25 \mathrm{~V}$ weld metal after PWHT; the ferrite grain size is only $\sim 10 \mu \mathrm{m}$. The microstructure with such fine grain size should not have low impact toughness at low temperature, but PWHT specimens only have $\sim 30 \mathrm{~J}$ impact absorbed energy. Therefore, this study focused on the effective microstructure at a specific area, such as the microstructure near the fracture initiation origin and the microstructure with retained cracks near the fracture surface. The retained cracks can exhibit a critical event, which is defined as the most difficult process of crack formation [34]. Thus, the vertical-section must be perpendicular to the fracture surface and located in the region nearly $250 \mu \mathrm{m}$ from the cleavage fracture initiation origin to observe the retained cracks [36]. The sampling method for the observed metallographic sections is explained in Section 2.5 and Figure 3.

The microstructure near the crack initiation origin on the cross-section is shown in Figure 8. The retained cracks on the vertical-section are displayed in Figure 9. Comparing Figures 8a and 4a, it can be seen that the microstructure near the crack initiation origin is different from that in the other zones in the as-welded specimen. The ferrite grains near the crack initiation origin are surrounded by several M-A constituents. From Figure 8a, it can be concluded that the microstructure near the crack initiation has two characteristics. First, the M-A constituents surrounded by ferrite cause stress concentration, which in turn, leads to crack initiation. The second characteristic is the presence of coarse ferrite phases, which do not appear elsewhere. The retained cracks of the as-welded impact specimen shown in Figure 9a and are propagated through bainitic ferrite. This suggests that the 
critical event in the as-welded specimen is the propagation of a grain-sized crack across the grain/grain boundary into contiguous grains.
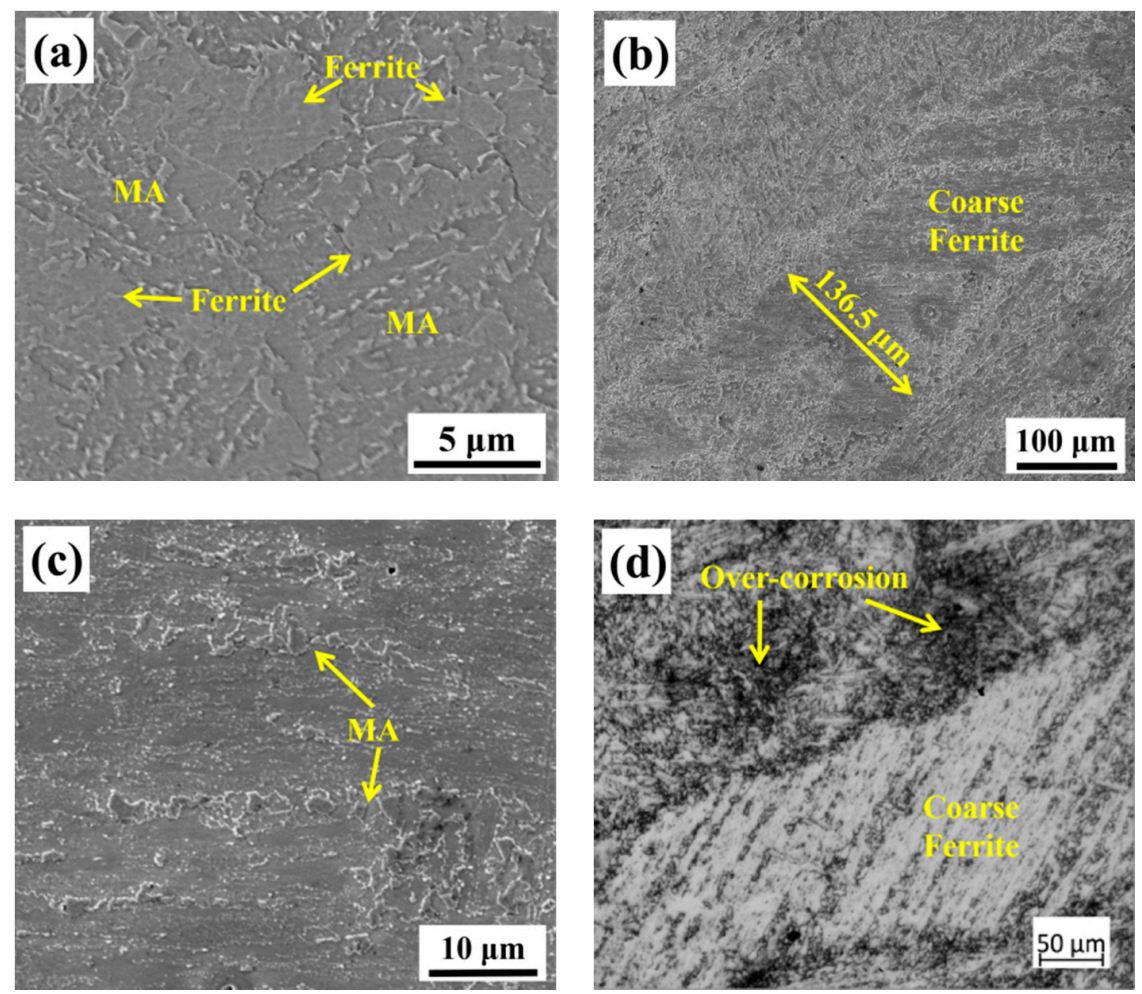

Figure 8. Microstructure of cross-section in Figure 3a for as-welded specimen (a), and for PWHT specimen $(\mathbf{b}-\mathbf{d})$.
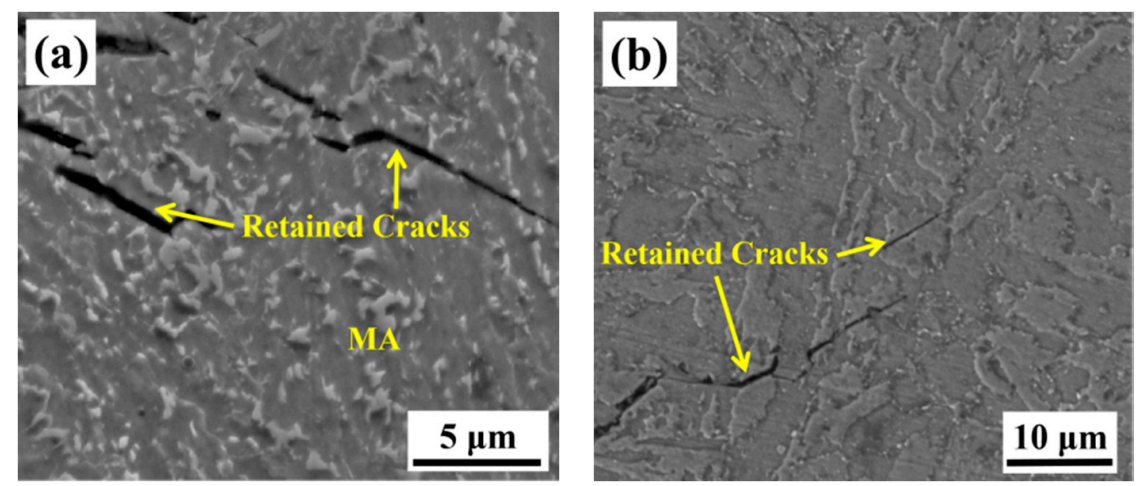

Figure 9. Retained cracks of vertical-section in Figure $3 \mathrm{~b}$ for as-welded specimen (a), and for PWHT specimen (b).

The microstructure near the crack initiation origin of the PWHT specimen is different from that of the as-welded specimen. A coarse ferrite appeared near the crack initiation zone, as shown in Figure $8 \mathbf{b}$, which represents the shape of the coarse ferrite with a width larger than $100 \mu \mathrm{m}$. It is obvious that the coarse ferrite is located in the columnar grain zone of the weld metal, and the length of the coarse ferrite is consistent with the length of the columnar grain zone. The coarse ferrite in Figure $8 \mathrm{c}$ is magnified in Figure $8 \mathrm{~b}$. No grain boundaries exist within the coarse ferrite, but some M-A constituents can be found. These M-A constituents were not decomposed by PWHT, which makes coarse ferrite more brittle. In order to eliminate the effect of the corrosion time on the coarse ferrite, the specimen was corroded again for a longer time by $5 \%$ Nital solution; the OM image is shown in Figure $8 \mathrm{~d}$. Although the ferrite beside the coarse ferrite already exhibited black traces of over-corrosion, 
no grain boundaries appeared within the coarse ferrite. The retained cracks propagated through the ferrite grain and stopped at the grain boundaries, as shown in Figure 9b. These transgranular retained cracks were hard to break through the ferrite grain boundaries, which means the size of retained cracks grew with grain size. According to the retained cracks in ferrites, the cracks in coarse ferrite will have the same length with coarse ferrites when cracks nucleate inside the coarse ferrite. Therefore, the critical event is confirmed as the propagation of a grain-sized crack across the grain/grain boundary into contiguous grains. This result is consistent with the theory in Equation (1); when the grain size is large, the low-temperature toughness decreases with the increase in the grain size. The coarse ferrite near the crack initiation origin can be regarded as the effective microstructure influencing low-temperature toughness.

\subsection{In Situ Observation of Microstructure Evolution}

As stated above, the coarse ferrite in the PWHT weld metal induces specimen fracture and leads to lower impact toughness. One of the characteristics of coarse ferrite is that it has the same length as the columnar grain zone. The OM images of the columnar grain zone are depicted in Figure 10. The prior austenite grain boundaries (PAGBs) of the as-welded and PWHT specimens, as shown in Figure 10a,b, maintain their columnar morphology during tempering heat treatment. It can be inferred that the primary columnar austenite formed during the welding process determined the size of the coarse ferrite.
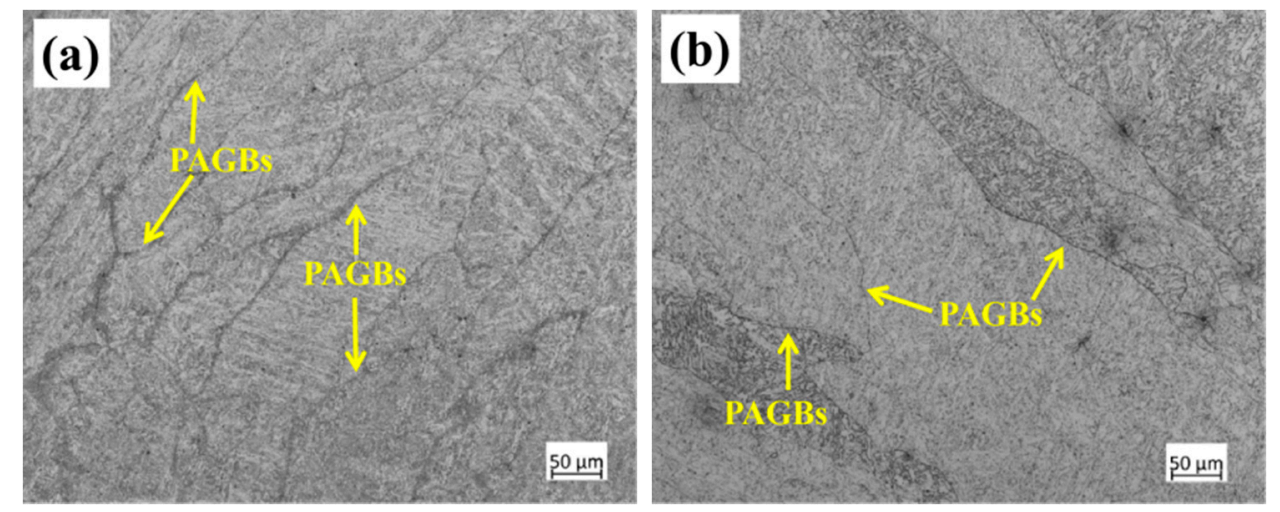

Figure 10. Optical microscopy (OM) images of columnar grain zone of (a) as-welded specimen and (b) PWHT specimen.

The in-situ observation of the evolution of prior austenite at high temperatures is required to identify the relationship between the prior austenite and the coarse ferrite. The in-situ observation of the evolution of prior austenite by CLSM is shown in Figure 11, Figure 12. Prior austenite first appeared at $1135^{\circ} \mathrm{C}$ in the heating stage, as shown in Figure 11a. As the heating temperature was higher than that in $\mathrm{Ac}_{3}\left(871^{\circ} \mathrm{C}\right)$, all the prior austenite phases were re-austenitized and homogenized to form fine austenite grains at the early heating stage. The average grain size is $39.6 \mu \mathrm{m}$, as shown in Figure 11a. Then, the prior austenite began to grow at the temperature holding stage. The high temperature of $1420^{\circ} \mathrm{C}$ accelerated the grain growth rate and made the observation of the grain boundary migration easier, as shown in Figure $11 \mathrm{~d}$. The prior austenite grain and statistical results of the grain size at the temperature holding stage are shown in Figure 11b-d. At the initial temperature holding stage, the average grain size only increased $15 \mu \mathrm{m}$ from the heating stage and reached $55.3 \mu \mathrm{m}$. As the temperature is continuously held, the boundary migration phenomena can appear on some fine austenite grain boundaries. At the same time, the fine grain boundaries disappeared and merged into coarse grains. Meanwhile, some austenite maintains its size, as shown in the dotted box. At the end of the temperature holding stage, the largest grain size was $291 \mu \mathrm{m}$, while the smallest was $19.5 \mu \mathrm{m}$. During the temperature holding stage, not only the prior austenite grain size changed, but some 
precipitation phases also appeared, as indicated by the arrows in Figure 11d. These precipitates, which were formed at high temperatures, became the inclusions after the cooling process of the weld metal.
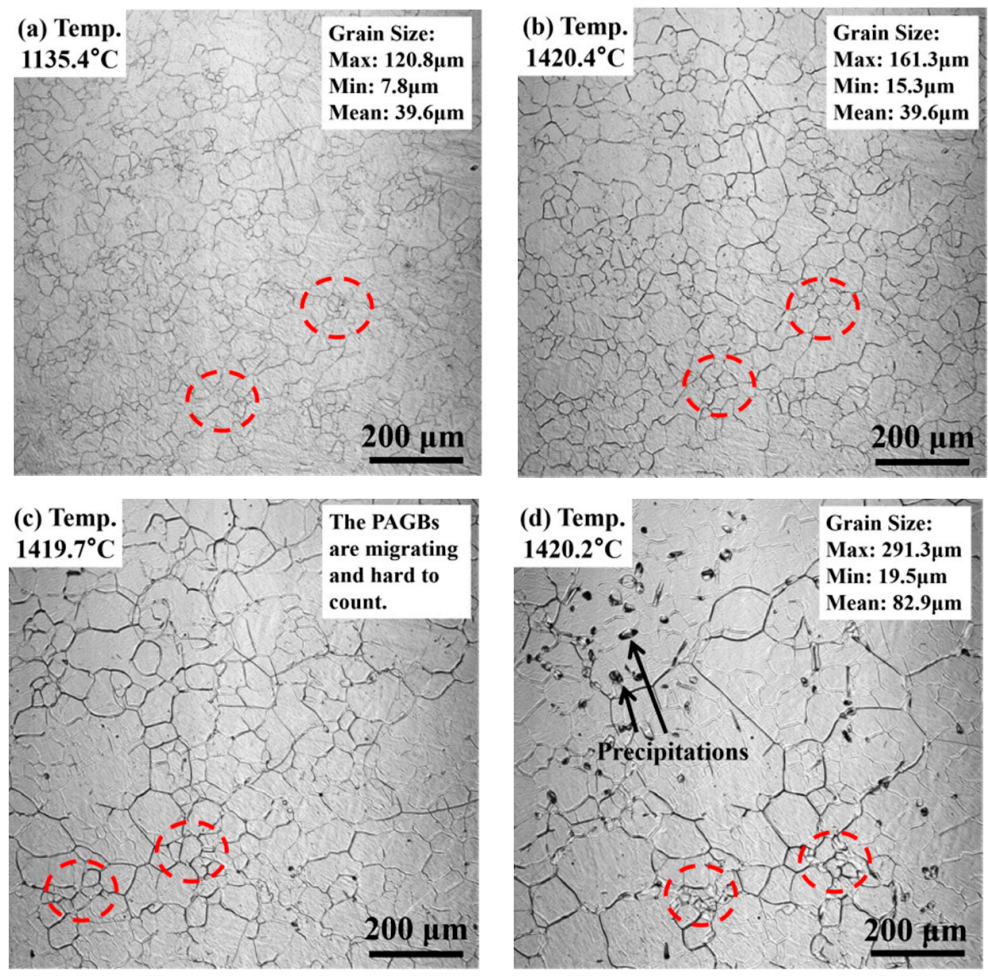

Figure 11. CLSM images of the weld metal for (a) heating stage, (b) initial stage of temperature holding stage, (c) temperature holding stage, (d) end stage of temperature holding stage.
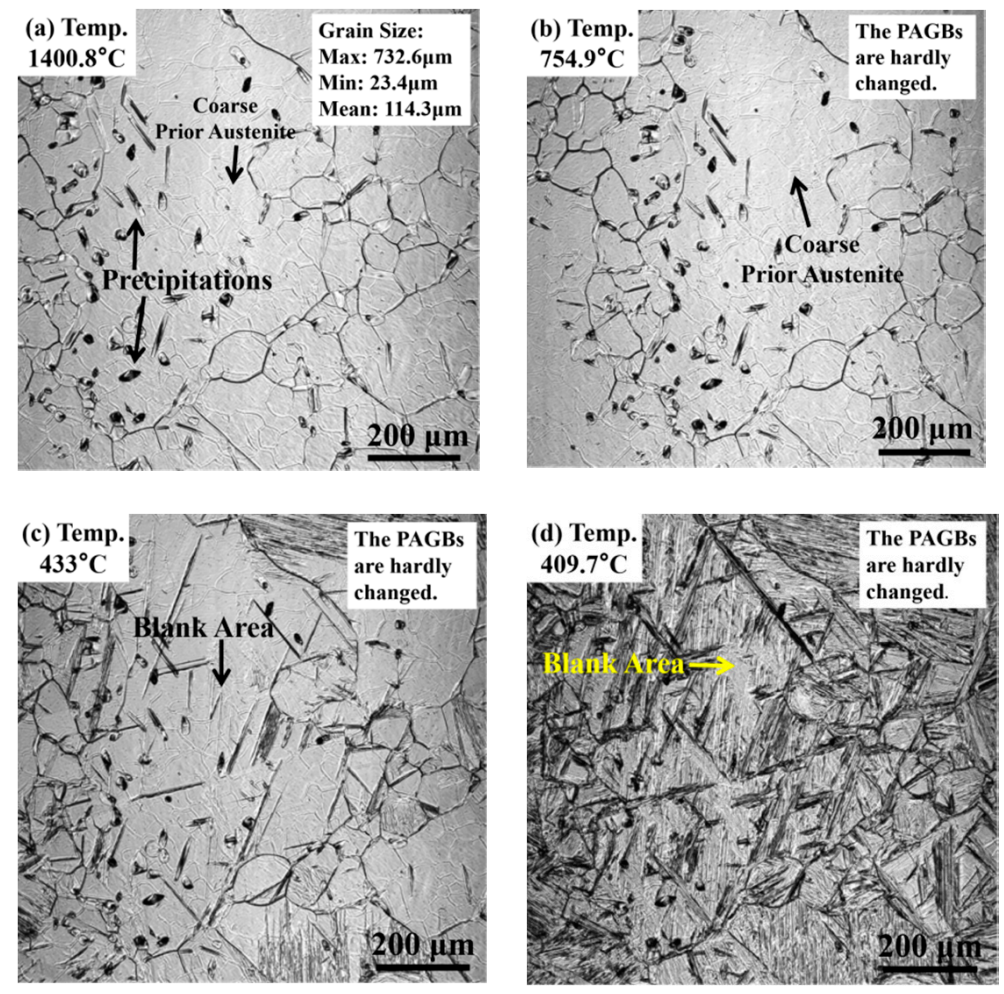

Figure 12. Confocal laser scanning microscopy (CLSM) images of the weld metal for (a) initial stage of cooling stage, (b) cooling stage at $754^{\circ} \mathrm{C},(\mathbf{c})$ cooling stage at $433{ }^{\circ} \mathrm{C},(\mathrm{d})$ end stage of cooling stage. 
The variation of prior austenite during the cooling stage is shown in Figure 12a-d. This study selected another area of observation, which has coarse prior austenite with a columnar-like shape. The grain size of the coarse prior austenite is $\sim 732 \mu \mathrm{m}$, while that of the minimum grain is $\sim 23.4 \mu \mathrm{m}$. Both the coarse prior austenite and the fine prior austenite maintain their size, and no new prior austenite grain boundaries are formed at the cooling stage. When the specimen is cooled to $440{ }^{\circ} \mathrm{C}$, several lath microstructures begin to grow. The lath microstructure nucleates at the prior austenite grain boundaries and inclusions then grows in the inside of the grain. The growth of the lath microstructure reflects the relationship between the coarse ferrite and the prior austenite. The microstructure in the fine prior austenite can occupy the entire area of the grains, while that in the coarse prior austenite will leave a "blank area" with the same growth rate of the lath microstructure, as shown in Figure 12c,d. This "blank area" would form the coarse ferrite and become the effective microstructure of the impact specimen. The microstructure after cooling is shown in Figure 13. The lath microstructure is lath bainite and granular bainite confirmed by SEM image, which is different from the microstructure of the as-welded and PWHT specimens. This type of microstructure was formed by a cooling rate of $10^{\circ} \mathrm{C} / \mathrm{s}$, which is located between the air-cooled (in the as-welded specimen) and cooling rate of $55^{\circ} \mathrm{C} / \mathrm{h}$ (in the PWHT specimen).

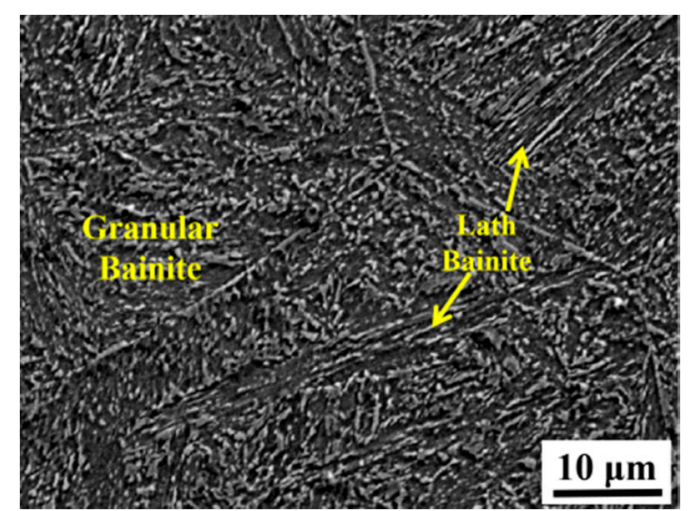

Figure 13. Microstructure of the specimen after CLSM.

\subsection{Improving the Low-Temperature Toughness of the Weld Metals}

Based on the above experimental results, improving the low-temperature impact toughness of the weld metals depends on either the decrease of the coarse ferrite or the decrease of the prior austenite grain size. Several studies concentrate on improving impact toughness by changing the elemental composition of the weld metal or the parameters of the PWHT process. This study attempted to improve the toughness by adjusting the manganese (Mn) content from 1.04 to $1.27 \mathrm{wt}$. \% with the other elemental concentrations and PWHT parameters remaining unchanged. The adjusted specimen was recorded as HM. The hardness of the HM specimen is $247 \mathrm{HV}$. The fracture surface and crack initiation origins and the corresponding low-temperature impact toughness values for the four parameters of the HM specimens are shown in Figure 14 and Table 3, respectively. From Table 3, the impact toughness can be improved from a range of 30-36 J to one of 95-157 J after increasing the manganese concentration. The fibrous crack length (SCL) region with more tear ridges becomes more extensive, as shown in Figure 14. The microstructure of the HM specimen cross-section cutting from the impact fractured specimens is shown in Figure 15. Some acicular ferrite (AF) with inclusions appear in the HM weld metal specimen. The elemental composition of the inclusions was measured via EDS analysis, as shown in Table 4. It can be inferred that the Mn-Si-O inclusions serve as the nucleation sites for the acicular ferrite with the increase of Mn content. 

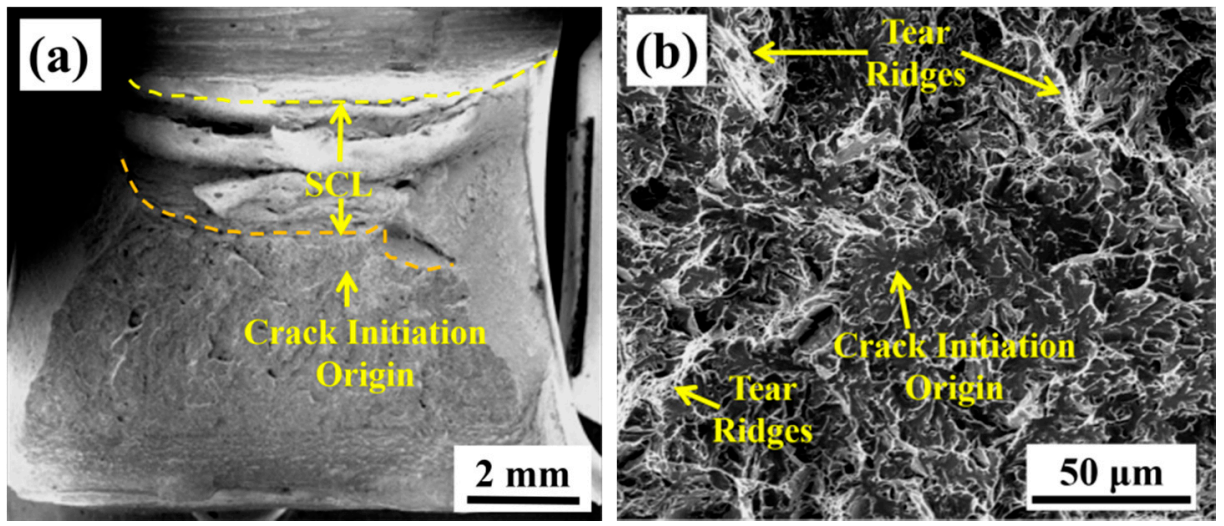

Figure 14. Fracture surface of HM specimen for (a) marco, (b) crack initiation origin.

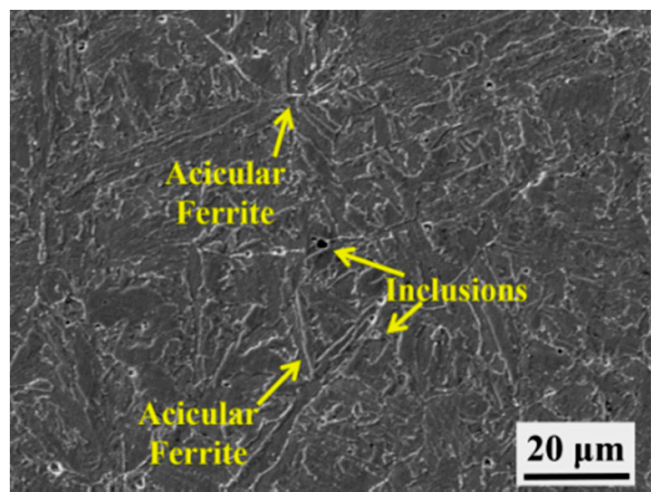

Figure 15. Microstructure of HM specimen.

Table 4. Chemical compositions of inclusions in $\mathrm{HM}$ specimen ( $\mathrm{w} \mathrm{t} \%)$.

\begin{tabular}{ccccccccc}
\hline $\mathbf{O}$ & $\mathbf{M n}$ & $\mathbf{S i}$ & $\mathbf{C}$ & Al & Fe & V & Al & Mo \\
\hline 41.73 & 21.92 & 16.79 & 6.11 & 3.58 & 4.03 & 3.92 & 3.58 & 1.82 \\
\hline
\end{tabular}

\section{Discussion}

\subsection{The Effect of Type of the Microstructure on Mechanical Properties of the Weld Metals}

The difference of the mechanical properties for as-welded and PWHT specimens is actually attributed to the difference of the microstructure. The microstructure of as-welded specimen is granular bainite, which is composed of bainite ferrite and M-A constituents. The block M-A constituents are almost considered as strengthening phase. It is the reason why as-welded specimen has higher yield strength, ultimate tensile strength, and hardness, as shown in Table 2. However, from the critical event of an as-welded specimen, as shown in Figure 9a, M-A constituents cannot prevent cracks propagation. The martensite in M-A constituents can also be considered as brittle phase, which is harmful to the impact toughness. But in PWHT specimen, the M-A constituents have been decomposed to carbide precipitation by tempering heat treatment. In as-welded impact specimen, the microstructure nearby crack initiation origin is M-A constituents surrounded by ferrite phases as shown in Figure 8a. Due to stress concentration at M-A constituents, crack can be formed and propagates through the ferrite grain. Schematic diagram of microstructure and impact fracture surface of as-welded specimen is shown in Figure 16a. 
(a)

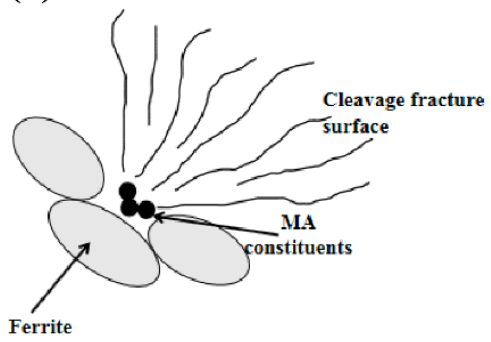

(b)

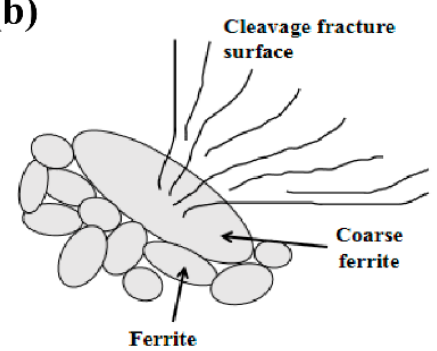

Figure 16. Schematic diagrams showing fracture processes for (a) as-welded impact specimen and (b) for PWHT impact specimen.

The hardness and yield strength of the PWHT specimen with ferrite microstructure are lower than that of as-welded specimen. Thus, lower yield strength leads to lower driving force to cleavage fracture, i.e., Lower $\sigma_{y y}=\mathrm{Q} \sigma_{\mathrm{y}}$, where $\sigma_{\mathrm{y}}$ is the normal tensile stress, $\sigma_{\mathrm{yy}}$ is the normal tensile stress ahead of the notch root and $Q$ is stress strengthening coefficient [34]. So, the PWHT specimen fractures at higher applied load, that is, higher impact toughness can be obtained.

The increase of Mn content leads to the appearance of the acicular ferrite in HM specimen. Since acicular ferrite has characteristics of fine size and high density of high angle grain boundaries, it will twist crack propagation path and absorb more energy during impact test [37-39]. The acicular ferrite improves the Charpy impact toughness of the weld metal.

\subsection{The Effect of Ferrite Grain Size on Impact Toughness of the Weld Metals}

Criteria for crack propagation from Griffth [40] and Orowan [41] should be considered to identify the relationship between microstructure and toughness. The formula for cleavage fracture stress $\sigma_{\mathrm{f}(\mathrm{f})}$ is given by:

$$
\sigma_{\mathrm{f}(\mathrm{f})}=\sqrt{\frac{2 E \gamma}{\pi\left(1-v^{2}\right) \mathrm{c}}}
$$

where $E$ is the Young's Modulus, $\gamma$ is the surface energy, $v$ is the Poisson's ratio, and $c$ is the half crack length. The equation gives the relationship between the size of the critical event and cleavage fracture. Based on the Griffith formula (Equation (2)), J.H. Chen et al. [42-44] put forward three types of critical events for cleavage fracture, which are defined as the most difficult stage of crack formation. The first is crack nucleation as the critical event, the second is the propagation of a second-phase particle-sized crack across the particle/grain boundary into a contiguous matrix as the critical event, and the third is the propagation of a grain-sized crack across the grain/grain boundary into contiguous grains as the critical event. The criterion of the third critical event [44] is

$$
\sigma_{\mathrm{yy}} \geq \sigma_{\mathrm{f}(\mathrm{f})}
$$

where $\sigma_{\mathrm{yy}}$ is the normal tensile stress and $\sigma_{\mathrm{f}(\mathrm{f})}$ is cleavage fracture stress. The relationship between the crack and grain size in this critical event, $\sigma_{\mathrm{f}(\mathrm{f})}$, in Equation (2) can be represented by Equation (4) [44].

$$
\sigma_{\mathrm{f}(\mathrm{f})}=\sqrt{\frac{2 E \gamma}{\pi\left(1-v^{2}\right) D}}
$$

where $\mathrm{D}$ is the grain size, which is the only microstructural variable determining the cleavage fracture stress. In other words, fine grain size contributes to the increase of impact toughness. From Figure $9 \mathrm{~b}$, the critical event of the PWHT impact specimen is the propagation of a grain-sized crack across the grain/grain boundary. Equation (4) is suitable for this situation, and the relationship between grain size and impact toughness is confirmed in the weld metal. 
Although the higher impact toughness can be obtained after PWHT as discussed in Section 4.1, the effective microstructure of PWHT impact specimen is that of coarse ferrite near the crack initiation, as shown in Figure 8b. With the critical event and the relationship between grain size and crack, the appearance of the coarse ferrite grain in the PWHT specimen makes the crack readily propagate through the coarse ferrite grain and stop at grain boundaries, so that the low impact toughness of the PWHT specimen cannot satisfy the requirement of toughness. The schematic diagram of the microstructure and impact fracture of the PWHT specimen is shown in Figure 16b.

\subsection{The Effect of Prior Austenite on Low-Temperature Impact Toughness of the Weld Metals}

According to the experimental result of the in-situ observation of the evolution of prior austenite by CLSM, a region of the fine prior austenite in the weld metal can become coarser and reach the same width as the columnar grain zone, whereas the others remain finely sized in the welding process. The coarse prior austenite grain determines the formation of the coarse ferrite in the weld metal. The size of the prior austenite also directly affects the level of impact toughness. The Hall-Petch relationship has a formula (Equation (5)) for the ductile-brittle transition temperature, which reveals the relationship between the grain size and mechanical properties [45].

$$
T_{B}=T_{0}-k_{B} \times d^{-\frac{1}{2}}
$$

In Equation (5), $T_{B}$ is the ductile-brittle transition temperature, $T_{0}$ is the initial value of $T_{B}$ when $d \rightarrow \infty, k_{B}$ is coefficient, and $d$ is prior austenite size. With the increase of the prior austenite grain size, the ductile-brittle transition temperature is also increased. Thus, the low-temperature toughness is decreased. In recent years, the toughness of high-strength low alloy steel can be improved by refining the prior austenite grain, because the fine prior austenite increases the density of PAGBs and high angle grain boundaries [46,47]. In fact, the refinement of prior austenite results in a finer packet/block size of the microstructure.

As stated above, in the weld metal, a portion of the prior austenite grew into coarse prior austenite in the welding process. The coarse prior austenite affects low-temperature impact toughness in two aspects. First, the over-sized prior austenite directly results in the reduction of toughness due to the Hall-Petch relation. Second, the over-sized prior austenite can form coarse ferrite phases, which become the effective microstructure of crack initiation.

\subsection{The Effect of Mn Content and Inclusions on the Low-Temperature Impact Toughness of the Weld Metals}

The low-temperature impact toughness of the weld metals increases from the 30-36 J range to the 95-157 J range by adjusting the Mn content from 1.04 to $1.27 \mathrm{wt} . \%$ due to the formation of $\mathrm{Mn}-\mathrm{Si}-\mathrm{O}$ inclusions and acicular ferrite. The Mn-Si-O inclusion is a kind of complex particle and acts as nucleation site of acicular ferrite [48-51]. The oxide particles offer cation vacancies and become preferential nucleation site of precipitation of MnS. With the increase of Mn content, Mn-depleted zone increased in matrix, which offer enough nucleation energy to contribute to acicular ferrite nucleation.

Mn can improve the hardenability, thereby increasing the strength and hardness of the ferrite and austenite in steels [48]. Generally, the increase in Mn content can compensate for the loss of strength resulting from reducing the carbon content. Mn can also significantly reduce the transformation temperature (bainite transformation temperature, Bs, and martensite transformation temperature, $\mathrm{Ms}$ ), which helps to improve the stability of the overcooled austenite.

\section{Conclusions}

In the present study, the relationship between low-temperature impact toughness and microstructure in the $2.25 \mathrm{Cr}-1 \mathrm{Mo}-0.25 \mathrm{~V}$ weld metal was investigated. The four main factors are proposed: type of microstructure, grain size, prior austenite, and inclusions. 
The microstructure of the as-welded weld metal and PWHT specimens $\left(705^{\circ} \mathrm{C}, 8 \mathrm{~h}\right)$ is composed of granular bainite and ferrite, respectively. The low-temperature impact toughness is increased from 6-7 J for the as-welded specimens to $30-36 \mathrm{~J}$ for the PWHT specimens $\left(705^{\circ} \mathrm{C}, 8 \mathrm{~h}\right)$ due to the difference in the microstructure type. The effective microstructures of crack initiation of the as-welded $2.25 \mathrm{Cr}-1 \mathrm{Mo}-0.25 \mathrm{~V}$ weld metal are M-A constituents and ferrite, which caused fracture by stress concentration at the M-A constituents. The effective microstructure of crack initiation of the PWHT 2.25Cr-1Mo-0.25V weld metal is coarse ferrite. Coarse ferrite is more brittle and contributes to crack initiation and propagation. Coarse ferrite phases can be formed in coarse prior austenite grains.

The impact of toughness can be improved by adjusting the Mn concentration in the $2.25 \mathrm{Cr}-1 \mathrm{Mo}-0.25 \mathrm{~V}$ weld metal. The increase in the Mn content from 1.04 to $1.27 \mathrm{wt} . \%$ leads to the formation of Mn-Si-O inclusions and acicular ferrite.

Author Contributions: Conceptualization, Y.Y., R.C. and J.C.; data curation, K.W.; funding acquisition, R.C.; investigation, K.W.; methodology, K.W., Y.Y., R.C., X.L. and J.C.; project administration, X.L.; resources, X.L., Y.J., X.J. and F.Y.; software, K.W.; supervision, Y.Y., R.C., Y.J., F.Y. and J.C.; validation, K.W. and X.J.; writing-original draft, K.W.; writing-review and editing, K.W. and R.C. All authors have read and agreed to the published version of the manuscript.

Funding: This work was financially supported by National Nature Science Foundation of China (Nos. 51761027, 51675255). The Foundation of Collaborative Innovation Teams in College of Gansu Province (2017C-07) and Lanzhou Science and Technology Department Project (2019-1-49).

Acknowledgments: Thanks for the financial and technical support of Atlantic China Welding Consumables and Lanzhou University of Technology.

Conflicts of Interest: The authors declare no conflict of interest.

\section{References}

1. Masuyama, F. History of Power Plants and Progress in Heat Resistant Steels. ISIJ. Int. 2001, 41, $612-625$. [CrossRef]

2. Avazkonandehgharavol, M.H.; Haddadsabzevar, M.; Haerian, A. Effect of chromium content on the microstructure and mechanical properties of multipass MMA, low alloy steel weld metal. J. Mater. Sci. 2009, 44, 186-197. [CrossRef]

3. Jorge, J.C.F.; de Souza, L.F.G.; Rebello, J.M.A. The effect of chromium on the microstructure/toughness relationship of C-Mn weld metal deposits. Mater. Charact. 2001, 47, 195-205. [CrossRef]

4. Bhole, S.D.; Nemade, J.B.; Collins, L.; Liu, C. Effect of nickel and molybdenum additions on weld metal toughness in a submerged arc welded HSLA line-pipe steel. J. Mater. Process. Technol. 2006, 173, 92-100. [CrossRef]

5. Yang, G.; Sun, X.; Li, Z.; Li, X.; Yong, Q. Effects of vanadium on the microstructure and mechanical properties of a high strength low alloy martensite steel. Mater. Des. 2013, 50, 102-107. [CrossRef]

6. Show, B.K.; Veerababu, R.; Balamuralikrishnan, R.; Malakondaiah, G. Effect of vanadium and titanium modification on the microstructure and mechanical properties of a microalloyed HSLA steel. Mater. Sci. Eng. A 2010, 527, 1595-1604. [CrossRef]

7. Cheruvu, N.S. Degradation of mechanical properties of $\mathrm{Cr}-\mathrm{Mo}-\mathrm{V}$ and 2.25Cr-1Mo steel components after long-term service at elevated temperatures. Metall. Mater. Trans. A 1989, 20,87-97. [CrossRef]

8. Klueh, R.L.; Swindeman, R.W. The microstructure and mechanical properties of a modified 2.25Cr-lMo steel. Metall. Mater. Trans. A 1986, 17, 1027-1034. [CrossRef]

9. Ahmed, S.R.; Agarwal, L.A.; Daniel, S.B.S. Effect of Different Post Weld Heat Treatments on the Mechanical properties of Cr-Mo Boiler Steel Welded with SMAW Process. Mater. Today 2015, 2, 1059-1066. [CrossRef]

10. Jiang, Z.; Wang, P.; Li, D.; Li, Y. Effects of tempering temperature on the microstructure and mechanical properties of granular bainite in 2.25 Cr-1Mo-0.25 V steel. Acta Metall. Sin. 2015, 51, 925-934.

11. Jiang, Z.; Wang, P.; Li, D.; Li, Y. Influence of the decomposition behavior of retained austenite during tempering on the mechanical properties of 2.25Cr-1Mo-0.25 V steel. Mater. Sci. Eng. A 2019, 742, 540-552. [CrossRef]

12. Jiang, Z.; Wang, P.; Li, D.; Li, Y. The evolutions of microstructure and mechanical properties of 2.25Cr-1Mo-0.25V steel with different initial microstructures during tempering. Mater. Sci. Eng. A 2017, 699, 165-175. [CrossRef] 
13. Ohtani, T.; Ogi, H.; Hirao, M. Evolution of microstructure and acoustic damping during creep of a Cr-Mo-V ferritic steel. Acta Mater. 2006, 54, 2705-2713. [CrossRef]

14. Zhang, Y.; Han, H.; Miao, L.; Zhang, H.; Li, J. Quantitative carbide analysis using the Rietveld method for 2.25Cr-1Mo-0.25V steel. Mater. Charact. 2009, 60, 953-956.

15. Fu, R.; Wang, T.S.; Zhou, W.H.; Zhang, W.H.; Zhang, F. Characterization of precipitates in a 2.25Cr-1Mo-0.25V steel for large-scale cast-forged products. Mater. Charact. 2007, 58, 968-973. [CrossRef]

16. Han, C.; Li, K.; Liu, X.; Cao, R.; Cai, Z. Effect of Ti content and martensite-austenite constituents on microstructure and mechanical property. Sci. Technol. Weld. Join. 2018, 23, 410-419. [CrossRef]

17. Lee, K.; Lee, S.; Na, H.; Kang, C. Ghost microstructure evolution and identification in the coarse grain heat affected zone of 2.25Cr-1Mo-V-Ti steel using tint etching. Mater. Charact. 2016, 121, 31-39. [CrossRef]

18. Rodriguezgaleano, K.F.; Rodriguezbaracaldo, R.; Mestrarodriguez, A.; Cabreramarrero, J.M.; Olayaflorez, J.J. Influence of boron content on the fracture toughness and fatigue crack propagation kinetics of bainitic steels. Theor. Appl. Fract. Mech. 2016, 86, 351-360. [CrossRef]

19. Jiang, Z.; Wang, P.; Li, D.; Li, Y. Effects of Rare Earth on Microstructure and Impact Toughness of Low Alloy Cr-Mo-V Steels for Hydrogenation Reactor Vessels. J. Mater. Sci. Technol. 2020, 45, 1-14. [CrossRef]

20. Xu, Y.W.; Song, S.H.; Wang, J. Effect of rare earth cerium on the creep properties of modified $9 \mathrm{Cr}-1 \mathrm{Mo}$ heat-resistant steel. Mater. Lett. 2015, 161, 616-619. [CrossRef]

21. Kawashima, F.; Tokiyoshi, T.; Igari, T.; Kanaya, A.; Hiroe, T.; Takao, N. Prediction of crack growth in CrMoV cast steel after long-term service at high temperature. Mater. Sci. Eng. A 2009, 510, 149-153. [CrossRef]

22. Lee, C.; Seol, W.; Kim, B.H.; Kim, S.; Jang, J.H.; Lee, T.; Moon, S.; Kim, S. Investigation on new type of fracture in Cr-Mo-V steel slab. Eng. Fail. Anal. 2019, 98, 240-248. [CrossRef]

23. Davis, C.L.; King, J.E. Effect of cooling rate on intercritically reheated microstructure and toughness in high strength low alloy steel. Mater. Sci. Technol. 1993, 9, 8-15. [CrossRef]

24. Elrefaey, A.; Javadi, Y.; Francis, J.A.; Callaghan, M.D.; Leonard, A.J. Evolution of microstructure and toughness in 2.25Cr-1Mo steel welds. Int. J. Pres. Ves. Pip. 2018, 165, 20-28. [CrossRef]

25. Aucott, L.; Wen, S.W.; Dong, H. The role of Ti carbonitride precipitates on fusion zone strength-toughness in submerged arc welded linepipe joints. Mater. Sci. Eng. A 2015, 622, 194-203. [CrossRef]

26. Song, H.Y.; Evans, G.M.; Babu, S.S. Effect of microstructural heterogeneities on scatter of toughness in multi-pass weld metal of C-Mn steels. Sci. Technol. Weld. Join. 2014, 19, 376-384. [CrossRef]

27. Wang, X.L.; Nan, Y.R.; Xie, Z.J.; Tsai, Y.T.; Yang, J.R.; Shang, C. Influence of welding pass on microstructure and toughness in the reheated zone of multi-pass weld metal of $550 \mathrm{MPa}$ offshore engineering steel. Mater. Sci. Eng. A 2017, 702, 196-205. [CrossRef]

28. Zhao, M.S.; Chiew, S.P.; Lee, C.K. Post weld heat treatment for high strength steel welded connections. J. Constr. Steel Res. 2016, 122, 167-177. [CrossRef]

29. Rabiei, A.; Derakhshandeh-Haghighi, R. Studying the Effect of PWHT on Microstructural Evolution and Mechanical Properties of Welded A517 Quenched and Tempered Steel. J. Mater. Eng. Perform. 2017, 26, 4567-4577. [CrossRef]

30. Aloraier, A.S.; Joshi, S.; Price, J.W.H.; Alawadhi, K. Hardness, Microstructure, and Residual Stresses in Low Carbon Steel Welding with Post-weld Heat Treatment and Temper Bead Welding. Metall. Mater. Trans. A 2014, 45, 2030-2037. [CrossRef]

31. Manugula, V.L.; Rajulapati, K.V.; Reddy, G.M.; Rao, K.B.S. Role of evolving microstructure on the mechanical properties of electron beam welded ferritic-martensitic steel in the as-welded and post weld heat treated states. Mater. Sci. Eng. A 2017, 698, 36-45. [CrossRef]

32. Luo, X.; Chen, X.; Wang, T.; Pan, S.; Wang, Z. Effect of morphologies of martensite-austenite constituents on impact toughness in intercritically reheated coarse-grained heat-affected zone of HSLA steel. Mater. Sci. Eng. A 2018, 710, 192-199. [CrossRef]

33. Cao, R.; Yuan, J.J.; Xiao, Z.G.; Ma, J.Y.; Mao, G.; Zhang, X.; Chen, J.H. Sources of Variability and Lower Values in Toughness Measurements of Weld Metals. J. Mater. Eng. Perform. 2017, 26, 2472-2483. [CrossRef]

34. Cao, R.; Chan, Z.S.; Yuan, J.J.; Han, C.Y.; Xiao, Z.G.; Zhang, X.; Yan, Y.J.; Chen, J.H. The effects of Silicon and Copper on microstructures, tensile and Charpy properties of weld metals by refined X120 wire. Mater. Sci. Eng. A 2018, 718, 350-362. [CrossRef]

35. Pickering, F.B.; Gladman, T. Metallurgical developments in carbon steels. ISI Spec. Rep. 1961, 81, 10-20. 
36. Mao, G.; Cayron, C.; Cao, R.; Loge, R.E.; Chen, J. The relationship between low-temperature toughness and secondary crack in low-carbon bainitic weld metals. Mater. Charact. 2018, 145, 516-526. [CrossRef]

37. Babu, S.S. The mechanism of acicular ferrite in weld deposits. Curr. Opin. Solid State Mater. Sci. 2004, 8, 267-278. [CrossRef]

38. Farrar, R.A.; Harrison, P.L. Acicular ferrite in carbon-manganese weld metals: An overview. J. Mater. Sci. 1987, 22, 3812-3820. [CrossRef]

39. Costin, W.; Lavigne, O.; Kotousov, A. A study on the relationship between microstructure and mechanical properties of acicular ferrite and upper bainite. Mater. Sci. Eng. A 2016, 663, 193-203. [CrossRef]

40. Griffith, A.A. The Phenomena of Rupture and Flow in Solids. Philos. Trans. R. Soc A 1921, 221, $163-198$.

41. Orowan, E. Energy criteria of fracture. Weld Res. 1955, 35, 379-386.

42. Chen, J.H.; Wang, G.Z.; Ma, H. Fracture behavior of C-Mn steel and weld metal in notched and precracked specimens: Part II. micromechanism of fracture. Metall. Mater. Trans. A 1990, 21, 321-330. [CrossRef]

43. Chen, J.H.; Wang, G.Z.; Yan, C.; Ma, H.; Zhu, L. Advances in the mechanism of cleavage fracture of low alloy steel at low temperature. Part II: Fracture model. Int. J. Fract. 1997, 83, 121-138. [CrossRef]

44. Chen, J.H.; Wang, G.Z.; Yan, C.; Ma, H.; Zhu, L. Advances in the mechanism of cleavage fracture of low alloy steel at low temperature. Part III: Local fracture stress $\sigma$. Int. J. Fract. 1997, 83, 139-157. [CrossRef]

45. Morris, J.J.; Lee, C.S.; Guo, Z. The Nature and Consequences of Coherent Transformations in Steel. ISIJ. Int. 2003, 43, 410-419. [CrossRef]

46. Wu, B.; Wang, X.; Wang, Z.; Zhao, J.; Jin, Y.; Wang, C.; Shang, C.; Misra, R. New insights from crystallography into the effect of refining prior austenite grain size on transformation phenomenon and consequent mechanical properties of ultra-high strength low alloy steel. Mater. Sci. Eng. A 2019, 745, 126-136. [CrossRef]

47. Lan, H.F.; Du, L.X. Improvement of strength-toughness combination in austempered low carbon bainitic steel: The key role of refining prior austenite grain size. J. Alloys Compd. 2017, 710, 702-710. [CrossRef]

48. Zhang, Z.; Farrar, R.A. Influence of $\mathrm{Mn}$ and $\mathrm{Ni}$ on the microstructure and toughness of C-Mn-Ni weld metals. Weld. J. 1997, 76, 183.

49. Zhuo, X.; Wang, X.; Wang, W.; Haegeon, L. Thermodynamic calculations and experiments on inclusions to be nucleation sites for intragranular ferrite in Si-Mn-Ti deoxidized steel. Int. J. Min. Met. Mater. 2007, 14, 14-21. [CrossRef]

50. Jaberi, F.S.; Kokabi, A.H. Influence of nickel and manganese on microstructure and mechanical properties of shielded metal arc-welded API-X80 steel. J. Mater. Eng. Perform. 2012, 21, 1447-1454. [CrossRef]

51. Yamamoto, K.; Hasegawai, T.; Takamura, J. Effect of Boron on Intra-granular Ferrite Formation in Ti-Oxide Bearing Steels. ISIJ. Int. 1996, 36, 80-86. [CrossRef] 